\title{
Concerning the Selective Protection of (Z)-1,5-syn-Ene-diols and (E)-1,5-anti-Ene-diols as Allylic Triethylsilyl Ethers
}

\author{
Jacqueline D. Hicks, Chan Woo Huh, Ashley D. Legg, and William R. Roush * \\ Department of Chemistry, Scripps Florida, Jupiter, FL 33458
}

\section{Abstract}

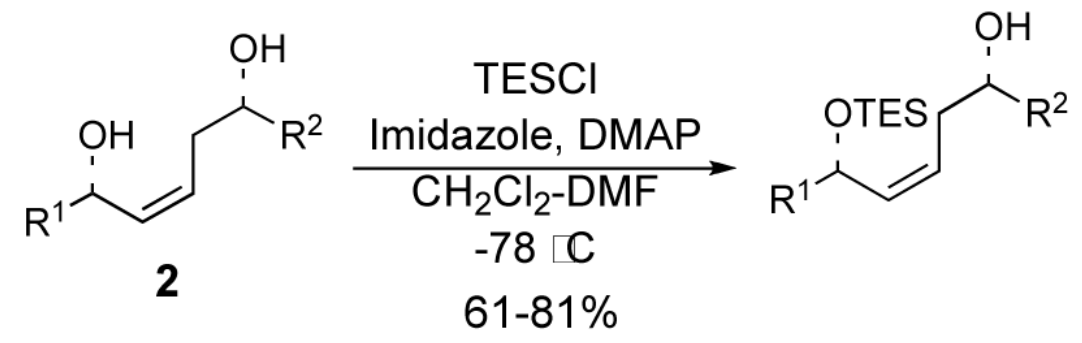

\section{$>95: 5$ (allylic : homoallylic ether)}

Treatment of unsaturated 1,5-diols 2 with TES-Cl (1.1 equiv), imidazole, and catalytic DMAP in 1 : $1 \mathrm{CH}_{2} \mathrm{Cl}_{2}$-DMF at $-78{ }^{\circ} \mathrm{C}$ effects selective silylation of the allylic alcohol with $>95: 5$ chemoselectivity when the allylic and homoallylic alcohols are in similar steric environments.

Our laboratory has reported a one-pot double allylboration reaction involving the sequential reaction of two aldehydes with the $\gamma$-boryl-substituted allylboranes $\mathbf{1}$ and $\mathbf{3}$ which provides (Z)-1,5-syn-diols 2 and (E)-1,5-anti-diols 4, respectively, with excellent diastereo- and enantioselectivity (Figure 1). ${ }^{1}$ In order to apply this method to the synthesis of structurally complex targets, including natural products, it is sometimes necessary to differentiate the two alcohols that result from the one-pot double allylboration reaction. ${ }^{2}$ We have previously reported that the allylic alcohol unit of $\mathbf{2}$ can be selectively protected with modest chemoselectivity as TBS ethers. ${ }^{3}$ We have examined this reaction in greater depth and report herein that optimal selectivity ( $\geq 95: 5$ ) is achieved by treating sterically unbiased diols 2 and 4 with triethylsilyl chloride (TES-Cl), imidazole, and catalytic DMAP in 1:1 $\mathrm{CH}_{2} \mathrm{Cl}_{2}$-DMF at $-78{ }^{\circ} \mathrm{C}$. This selective silylation of the allylic alcohol is attributed to subtle differences in the steric environment surrounding the two hydroxyl groups.

While examples are known of the selective silylation of a secondary allylic alcohol in the presence of a saturated secondary alcohol, the majority of cases involve sterically hindered or geometrically biased substrates in which the allylic alcohol undergoes preferential silylation. 4,5 Relatively few examples of chemoselective silylation of allylic alcohols in the presence of saturated alcohols on substrates that lack a steric bias have been reported. ${ }^{3,6}$ With this background in mind, we examined the selective protection of diol $5^{2 \mathrm{a}}$ (Table 1). Examination of reaction conditions previously applied to sterically unbiased substrates (TBS-Cl, imidazole, DMAP, $r t)^{3}$ provided a $39 \%$ yield of the mono-TBS ether consisting of an 86:14 mixture of

roush@scripps.edu.

Supporting Information Available Experimental procedures and tabulated spectroscopic data for all new compounds. This material is available free of charge via the Internet at http://pubs.acs.org. 
allylic silyl ether $\mathbf{6}$ and the corresponding homoallylic silyl ether (entry 1). After exploring other conditions, ${ }^{7}$ we found the yield and chemoselectivity of silylation could be improved though the use of the more reactive silylating reagent, TES-Cl, which allowed these reactions to proceed at lower reaction temperatures. Optimal reaction conditions involved treatment of 5 with 1.1 equiv of TES-Cl, imidazole (1.15 equiv), and DMAP (0.05 equiv) in $1: 1 \mathrm{CH}_{2} \mathrm{Cl}_{2^{-}}$ DMF at $-78^{\circ} \mathrm{C}$ (entry 3$) .^{8}$

The optimal silylation conditions defined for $\mathbf{5}$ provided high levels of selecitivity for allylic alcohol silylation with other unsaturated (Z)-1,5-syn-diols (Table 2). ${ }^{9}$ Pseudosymmetrical 1,5diols $\mathbf{8}^{1}$ and $\mathbf{1 0}^{6}$ which contain the same $\mathrm{R}^{1}$ and $\mathrm{R}^{2}$ substituents were silylated with excellent levels of chemoselectivity, providing nearly exclusive formation of the allylic silyl ether (entries 1 and 2). With substrates $\mathbf{1 0}$ and $\mathbf{1 2}$ (Entries 2 and 3) that have increased steric bulk around the 1,5-diol core, improved yields of the allylic monosilyl ethers $\mathbf{1 1}$ and $\mathbf{1 3}$ were obtained since formation bis-silyl ether product was suppressed ( $\leq 6 \%$ yield). The selective protection of dienylic alcohol 14, an intermediate in the synthesis of amphidinol $3,2 \mathrm{~b}$ proceeds in good yield and chemoselectivity $(76 \%,>97: 3$, entry 4$)$.

The scope of this selective protection reaction is not limited to $(Z)-1,5$-syn-diols, as $(E)-1,5$ anti-diols can also be monosilylated with good chemoselectivity (Table 3). Therefore, the selectivity for allylic alcohol silylation is not due to conformational effects specific to $(Z)-1,5$ syn-diols, e.g., deriving from $\mathrm{A}^{-1,3}$ interactions, ${ }^{10}$ or to an intramolecular hydrogen bonding network. ${ }^{11}$ Substrates 18 and $\mathbf{2 0}$ containing similar steric environments surrounding the allylic and homoallylic positions provided allylic silyl ethers 19 and 21 with $\geq 95: 5$ chemoselectivity. Increasing the size of the homoallylic subsutituent relative to the allylic subsutituent (22, entry 3 ) led to an improved yield of the allylic TES ether as less bis-silylation product was generated $(2 \%)$. Increasing the size of the group neighboring the allylic alcohol, relative to the subsutituent adjacent to the homoallylic alcohol, as in $\mathbf{2 4}$, led to decreased selectivity for allylic alcohol protection, although interestingly, silylation of this position was still favored (84:16, entry 4). Modification the sterics and electronics of the system by introduction of an ester at the homoallylic position (26) led to a decrease selectivity to for silylation of the allylic alcohol $(77: 22$, entry 5$)$.

We considered two hypotheses to account for the selective allylic alcohol silylation presented in Tables 2 and 3. The first hypothesis focused on the differences in acidities between allylic and homoallylic alcohols. Generally, the $\mathrm{pKa}$ of alcohols that are adjacent to an alkene or alkyne are lower than the corresponding saturated alcohols due to the increased electronegativity of the unsaturated substituents. ${ }^{12}$ The increased acidity of the allylic alcohol could potentially facilitate hydrogen bonding to the base, thereby increasing the nucleophilicity of the allylic alcohol relative to the homoallylic alcohol. The second hypothesis focused on the subtle differences in the steric environment surrounding the allylic and homoallylic alcohols -namely the additional hydrogen atom flanking the homoallylic position. This hypothesis was initially less appealing because it did not appear to account for the allylic selective silylation of (E)-1,5-anti-diol 24 (Table 3), which contained a more sterically demanding cyclohexyl ring adjacent to the allylic alcohol.

We decided to investigate the first hypothesis by adjusting the acidities of the allylic and homoallylic alcohols. To probe the effect of changing the $\mathrm{pKa}$ of the two hydroxyl groups, a series of substrates were synthesized that contained similar steric environments but differing electronic environments (Table 4). Silylation of 1,5-diol 28 containing phenyl groups in both the $\mathrm{R}^{1}$ and $\mathrm{R}^{2}$ positions provided an 88:12 mixture of regioisomers at room temperature. The placement of an electron-withdrawing group on the aryl ring neighboring the homoallylic alcohol as in $\mathbf{3 0}$ and $\mathbf{3 2}$ (entries 2 and 3, Table 4) was predicted to decrease the amount of allylic alcohol silylation due to the increased acidity of the homoallylic alcohol. ${ }^{13}$ However, 
TES protection of $\mathbf{3 0}$ and $\mathbf{3 2}$ resulted in increased allylic alcohol protection, providing $\mathbf{3 1}$ and 33 with 95:5 and 94:6 selectivity, respectively (at room temperature). The installment of an electron-withdrawing group on the aryl ring neighboring the allylic alcohol as in entry 4 (Table 4 , entry 4) resulted in a decrease in allylic selectivity, lowering the allylic:homoallylic silyl ether ratio to nearly 50:50. These results contradict the hypothesis that the greater acidity of the allylic alcohol results in preferential silylation. Rather, these results suggest instead that electron-withdrawing groups neighboring an alcohol affect selectivity by decreasing the nucleophilicity of that position (Table 4). 14,15

Data summarized in Table 5 for silylation of $\mathbf{8}$ with a series of trialkylsilyl chlorides are consistent with the second hypothesis that selective silylation of the allylic alcohol derives from the fact that the olefin adjacent to the allyic alcohol is less sterically demanding than the methylene group neighboring the homoallylic alcohol. The results summarized in Table 5 show the ratio of allylic to homoallylic silyl ether improves as the size and steric demands of the silyl chloride is increased.

We also investigated the relationship between the stoichiometry of triethylsilyl chloride and the yield and chemoselectivity of the selective silylation reaction (Table 6). We observed that increasing the equivalents of TES-Cl in the reaction led to an increase in the ratio of allylic:homoallylic silyl ether products, from 94:6 when 0.1 equiv of TES-Cl is used (entry 1) to $98: 2$ when 1.1 equiv of TES-Cl is used (entry 6). These data imply that some of the initially formed homoallylic mono-TES ether undergoes a second silylation to give the 1,5-bis-

protected ether $\mathbf{4 0}$ somewhat faster than the second silylation of homoallylic ether $\mathbf{9}$. It is quite clear from the data in Table 6 that homoallylic TES ether 9 is formed with excellent selectivity even at short conversion.

In conclusion, the selective protection of the allylic alcohol unit of unsaturated 1,5-diols 2 and 4 proceeds with high selectivity for substrates in which the allylic and homoallylic alcohols are in otherwise similar steric environments. These reactions are optimally executed at low temperatures using TES-Cl as the silylating agent, and provide the allylic TES ethers in good yields (typically $61-81 \%$ ). The decreased steric environment surrounding the allylic alcohol relative to that surrounding the homoallylic alcohol is invoked to rationalize the selective allylic alcohol silylation described herein.

\section{Supplementary Material}

Refer to Web version on PubMed Central for supplementary material.

\section{Acknowledgment}

This work was supported by the National Institutes of Health (GM038436).

\section{References}

1. Flamme EM, Roush WR. J. Am. Chem. Soc 2002;124:13644. [PubMed: 12431072]

2. (a) Hicks JD, Flamme EM, Roush WR. Org. Lett 2005;7:5509. [PubMed: 16288543] (b) Flamme EM, Roush WR. Org. Lett 2005;7:1411. [PubMed: 15787519] (c) Lira R, Roush WR. Org. Lett 2007;9:533. [PubMed: 17249805] (d) Owen RM, Roush WR. Org. Lett 2005;7:3941. [PubMed: 16119937]

3. Flamme EM, Roush WR. Beilstein J. Org. Chem 2005;1:7. [PubMed: 16542020]

4. (a) Chen S-H, Wei J-M, Vyas DM, Doyle TW, Farina V. Tetrahedron Lett 1993;34:6845. (b) Wyatt PG, Coomber BA, Evans DN, Jack TI, Fulton HE, Wonacott AJ, Colman P, Varghese J. Bioorg. Med. Chem. Lett 2001;11:669. [PubMed: 11266166] (c) Kaneko M, Nakashima T, Uosaki Y, Hara M, Ikeda S, Kanda Y. Bioorg. Med. Chem. Lett 2001;11:887. [PubMed: 11294384] (d) Horiguchi T, Oritani T, Kiyota H. Tetrahedron 2003;59:1529. (d) Nicolaou KC, Koftis TV, Vyskocil S, Petrovic G, Ling T, Yamada YMA, Tang W, Frederick MO. Angew. Chem. Int. Ed 2004;43:4318. (f) Jaunzems J, Kashin 
D, Schonberger A, Kirschning A. Eur. J. Org. Chem 2004:3435. (g) Cho JH, Dernard DL, Sidwell RW, Kern ER, Chu CK. J. Med. Chem 2006;49:1140. [PubMed: 16451078]

5. (a) Ramsay MVJ, Roberts SM, Russell JC, Shingler AH, Slawin AMZ, Sutherland DR, Tiley EP, Williams DJ. Tetrahedron Lett 1987;28:5353. (b) Bliard C, Escribano FC, Lukacs G, Olesker A, Sarda P. J. Chem. Soc., Chem. Comm 1987:368. (c) Banks BJ, Bishop BF, Evans NA, Gibson SP, Goudie AC, Gration KAF, Pacey MS, Perry DA, Witty MJ. Bioorg. Med. Chem 2000;8:2017. [PubMed: 11003146] (d) Konoki K, Sugiyama N, Murata M, Tachibana K, Hatanaka Y. Tetrahedron 2000;56:9003. (e) Crimmins MT, Katz JD, Washburn DG, Allwein SP, McAtee LF. J. Am. Chem. Soc 2002;124:5661. [PubMed: 12010038] (f) Nagai K, Sunazuka T, Omura S. Tetrahedron Lett 2004;45:2507.

6. (a) Karanewsky DS. Tetrahedron Lett 1991;32:3911. (b) Marco-Contelles J, de Opazo E. J. Org. Chem 2000;65:5416. [PubMed: 10993375] (c) Smith AB III, Adams CM, Barbosa SA, Degnan AP. J. Am. Chem. Soc 2003;125:350. [PubMed: 12517144] (d) Nakata M, et al. Tetrahedron Lett 2003;44:7747.

7. A table of other conditions examined during efforts to optimize the selectivity of silylation of diol $\mathbf{8}$ is provided in the Supporting Information.

8. The use of imidazole improved the selectivity for allylic alcohol silylation compared to other bases, while DMF and DMAP have little effect on chemoselectivity. See Supporting Information for details.

9. The identity of the major products as the allylic TES ethers was confirmed by acylation ( $\left.\mathrm{Ac}_{2} \mathrm{O}, \mathrm{DMAP}\right)$ of the homoallylic hydroxyl groups to give the homoallylic acetate that was characterized by ${ }^{1} \mathrm{H}$ NMR spectroscopy.

10. Hoffman RW. Chem. Rev 1989;89:1841.

11. Haines AH. Tetrahedron Lett 1969;15:1201.

12. The pKa of allyl alcohol is 15.5 while that of 1-propanol is 16.1. SerjeantEPDempseyBIonization Constants of Organic Acids in Aqueous Solution1979PergamonNew York, NYIUPAC Chemical Data Series, No. 23

13. (a) Marin MAB, Nome F, Zanette D, Zucco C, Romsted LS. J. Phys. Chem 1995;99:10879. (b) Strong LE, Brummel CL, Lindower P. J. Solution Chem 1987;16:105.

14. (a) Phan TB, Mayr H. Can. J. Chem 2005;83:1554. (b) Minegishi S, Mayr H. J. Am. Chem. Soc 2003;125:286. [PubMed: 12515531]

15. Example in 1,2-diol system: Sunazuka T, Hirose T, Harigaya Y, Takamatsu S, Hayashi M, Komiyama K, Omura S, Sprengeler PA, Smith AB III. J. Am. Chem. Soc 1997;119:10247. 


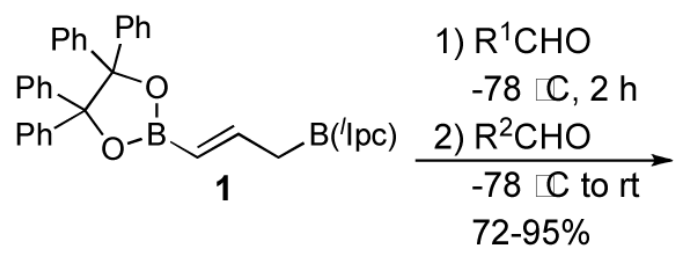

1) $\mathrm{R}^{1} \mathrm{CHO}$

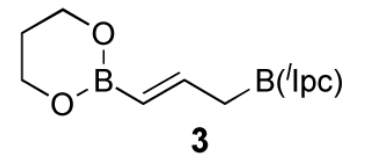

3

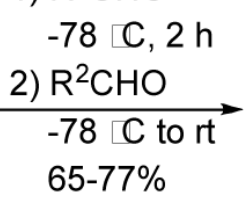

Figure 1.

Synthesis of (Z)-1,5-syn-diols and (E)-1,5-anti-diols. 
Hicks et al.

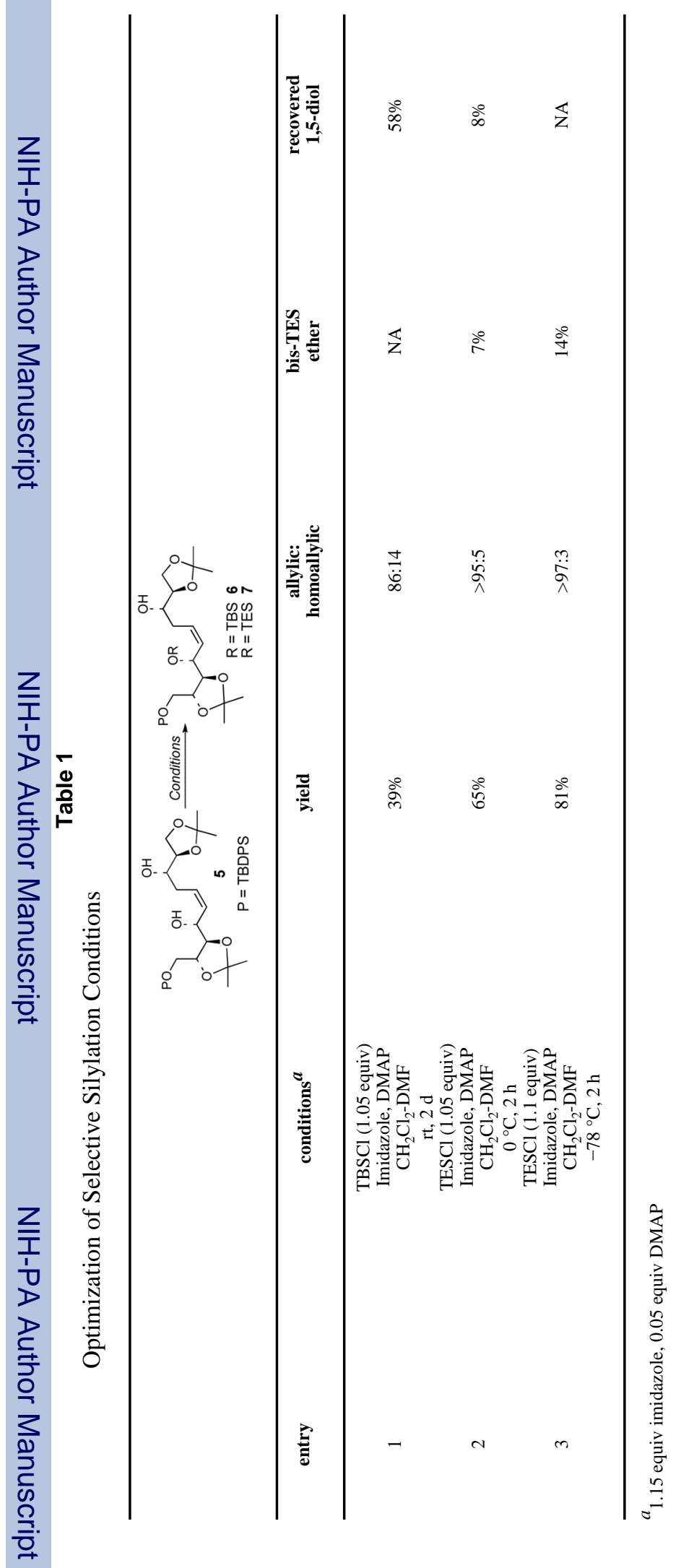

Org Lett. Author manuscript; available in PMC 2008 December 20. 
Table 2

Selective Protection of (Z)-1,5-syn-diols

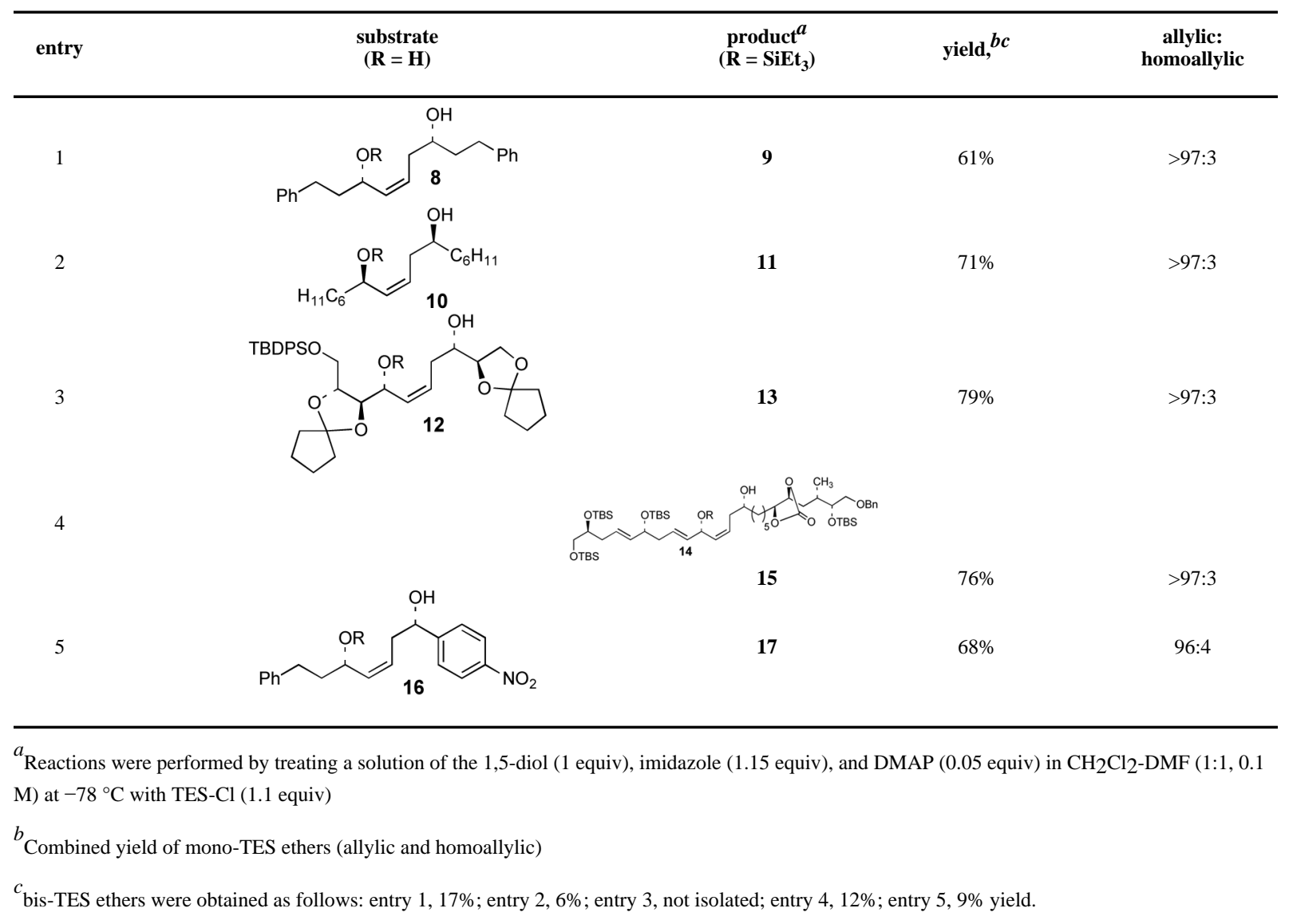


Table 3

Selective Protection of (E)-1,5-anti-diols

\begin{tabular}{|c|c|c|c|c|}
\hline entry & $\begin{array}{c}\text { substrate } \\
(\mathbf{R}=\mathbf{H})\end{array}$ & $\begin{array}{c}\text { product }^{a} \\
\left(\mathbf{R}=\mathrm{SiEt}_{3}\right)\end{array}$ & yield, ${ }^{b c}$ & $\begin{array}{c}\text { allylic: } \\
\text { homoallylic }\end{array}$ \\
\hline 1 & $\mathrm{OR}$ & 19 & $66 \%$ & $95: 5$ \\
\hline 2 & & 21 & $66 \%$ & $>97: 3$ \\
\hline 3 & & 23 & $79 \%$ & $>97: 3$ \\
\hline 4 & & 25 & $44 \%$ & $84: 16$ \\
\hline 5 & 26 & 27 & $58 \%$ & $77: 22$ \\
\hline
\end{tabular}

${ }^{a}$ Reactions were performed by treating a solution of the 1,5-diol (1 equiv), imidazole (1.15 equiv), and DMAP ( 0.05 equiv) in $\mathrm{CH}_{2} \mathrm{Cl}_{2}-\mathrm{DMF}_{\text {(1:1, } 0.1}$ M) at $-78^{\circ} \mathrm{C}$ with TES-Cl (1.1 equiv)

${ }^{b}$ Combined yield of mono-TES esters (allylic and homoallylic)

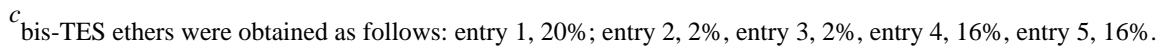


Table 4

Protection of Electronically Biased Substrates at Room Temperature

entry

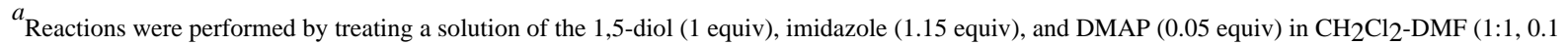
M) at rt with TES-Cl (1.1 equiv)

${ }^{b}$ Combined yield of mono-TES ethers (allylic and homoallylic) 
Variation of Silyl Chloride

Table 5

\begin{tabular}{|c|c|c|c|c|}
\hline & & $\begin{array}{c}\text { Silyl Chloride } \\
\text { Imidazole, DMAP } \\
\underset{\mathrm{CH}_{2} \mathrm{Cl}_{2} \text {-DMF }}{23 C}\end{array}$ & $\overbrace{\mathrm{R}}^{\mathrm{OH}-\mathrm{H}}$ & \\
\hline $\begin{array}{c}\text { silyl } \\
\text { chloride }^{a}\end{array}$ & bis-silyl & $\begin{array}{c}\text { mono-silyl } \\
9 \text { a-e }\end{array}$ & $\begin{array}{c}\text { allylic: } \\
\text { homoallylic }\end{array}$ & recov. SM \\
\hline TMS & $27 \%$ & $26 \%$ & $78: 22$ & $19 \%$ \\
\hline TESCl & $16 \%$ & $59 \%$ & $89: 11$ & $14 \%$ \\
\hline TBSCl & $8 \%$ & $55 \%$ & $89: 11$ & $33 \%$ \\
\hline TBDPSCl & $12 \%$ & $53 \%$ & $92: 8$ & $33 \%$ \\
\hline TIPS & $5 \%$ & $54 \%$ & $94: 6$ & $27 \%$ \\
\hline
\end{tabular}

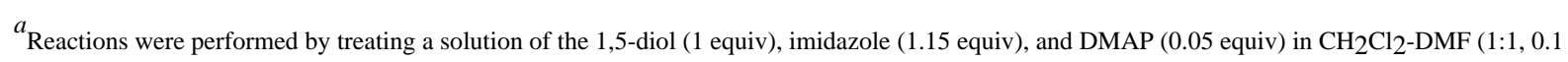
$\mathrm{M})$ at room temperature with silyl chloride (1.1 equiv) 
Table 6

Effect of Increasing Equiv of TES-Cl on Ratio of Allylic:Homoallylic Ethers.

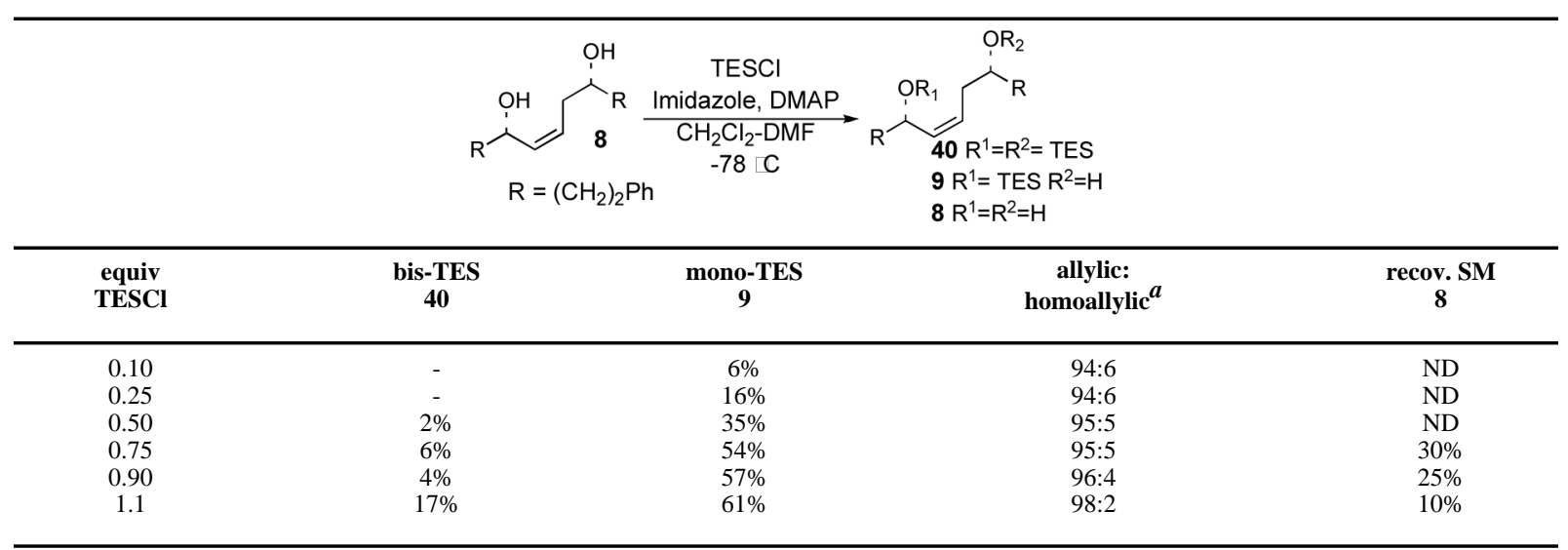

\footnotetext{
${ }^{a}$ Allylic:homoallylic TES ether ratio determined by NMR spectroscopy (integration of homoallylic protons; $\mathrm{S} / \mathrm{N}>200: 1$, relaxation delay (d1) of $\geq 6$ sec).
} 